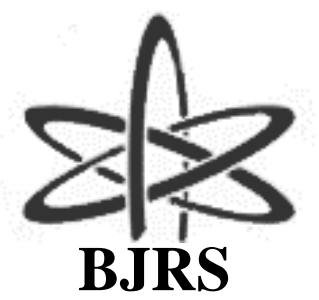

\author{
BRAZILIAN JOURNAL \\ $\mathrm{OF}$ \\ RADIATION SCIENCES \\ 07-2A (2019) 01-14
}

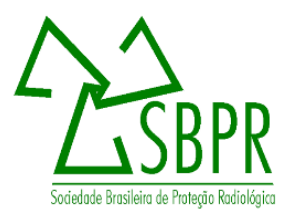

\title{
Influence of adsorption parameters on uranium adsorption capability by biochar derived from macauba coconut
} residue

\author{
S. N. Guilhen ${ }^{\mathrm{a}}$; J. Coleti ${ }^{\mathrm{b}}$; J. A. S. Tenório ${ }^{\mathrm{b}}$; D. A. Fungaro ${ }^{\mathrm{a}}$ \\ ${ }^{a}$ Comissão Nacional de Energia Nuclear, Instituto de Pesquisas Energéticas e Nucleares, Centro de Química e Meio \\ Ambiente, 05508-000, São Paulo, SP, Brasil. \\ snguilhen@ipen.br \\ ${ }^{b}$ Universidade de São Paulo, Escola Politécnica, Departamento de Engenharia Metalúrgica e de Materiais, 05508- \\ 030, São Paulo, SP, Brasil.
}

\begin{abstract}
Biochar (BC) is a carbon-rich product obtained when biomass is thermally decomposed at relatively low temperatures (under $700^{\circ} \mathrm{C}$ ) and limited supply of oxygen in a process called pyrolysis. Because of its porous structure, charged surface and surface functional groups, BC exhibits a great potential as an adsorbent. Its characteristics strongly depend on the feedstock and the pyrolysis conditions. The aim of this study was to evaluate the adsorption potential for the removal of uranium, U(VI) from aqueous solutions using BC obtained through slow pyrolysis of the macauba coconut endocarp. The influence of parameters such as $\mathrm{pH}$, sorbent dose and initial concentration on the adsorption of U(VI) was investigated. The $\mathrm{BC}$ obtained at $350{ }^{\circ} \mathrm{C}(\mathrm{BC} 350)$ presented a removal percentage of approx. $80 \%$, demonstrating its applicability for the treatment of uranium contaminated aqueous solutions.
\end{abstract}

Keywords: biochar, macauba, uranium, adsorption, pyrolysis.

ISSN: 2319-0612

Accepted: 2018-12-18 


\section{INTRODUCTION}

Radioactive uranium aqueous wastes emerge as a result of many distinct nuclear activities such as mining, research, fuel cycle and nuclear medicine. Environmental issues have become increasingly important in the last few decades especially due to the large number of uranium production facilities which have been taken out of operation recently. Decommissioning and rehabilitation have become a concern, since the remediation of formerly utilized sites involves a broad investigation of the environment and the extent to which it has been affected, before applying the necessary administrative and technical actions to restore it under the auspicious control of regulatory agencies [1].

Monitoring of the water from uranium mills is required to ensure that all constituents are within regulatory compliance. Equally, the treatment of uranium contaminated wastewater is essential before its discharge into the environment. Combined techniques and operations such as chemical precipitation, reverse osmosis, solvent extraction, micellar ultrafiltration and adsorption are normally required for the treatment of uranium contaminated wastewaters and liquid radioactive wastes [2, 3]. Among the possible techniques, adsorption stands out for its efficiency and specificity, requiring a simple design and low investment [4].

Several adsorbents for uranium have been reported in literature comprising biological adsorbents such as the fungus Aspergillus niger [5], the green algae Scenedesmus obliquus [6], the aquatic plant E. Canadensis [7] and the fungus Rhizopus arrhizus [8], inorganic adsorbents such as the modified bentonite [9] and organic adsorbents such as carbon microspheres [10] and IPN polymer [11].

Agricultural by-products have been studied as a sustainable solution for wastewater treatment [12], providing a wide range of renewable sources for the production of biochar, a porous stable material. Several studies have demonstrated that biochar can be applied for wastewater treatment because it effectively removes heavy metals from aqueous solutions [13, 14]. Biochars derived from pine needles, switchgrass, rice husk and eucalyptus [15-18] have been applied for uranium sorptive removal from aqueous solutions.

Biochar may be produced using slow pyrolysis technique, in which the biomass is heated to relatively low temperatures $\left(<700{ }^{\circ} \mathrm{C}\right)$ in the absence of oxygen [19]. Heating rate, residence time and 
temperature have a direct impact in the distribution and yield of each of the biochar [20, 21]. Of these parameters, the maximum temperature to which the biomass is subjected in the pyrolysis reactor, called highest treatment temperature (HTT) has the greatest overall influence on the biochar properties [22, 23, 24].

Macauba (Acrocomia aculeata) is a palm tree prevalent in the Brazilian savannah, which coconut is used to produce oil. As a residue of the nut-oil extraction, the endocarp has a potential to be used as feedstock for biochar production, because of its elevated lignin content [25]. By doing so, value is imparted to the residue.

In this study, the influence of parameters such as $\mathrm{pH}$, adsorbent dose and initial concentration on the adsorption of $\mathrm{U}(\mathrm{VI})$ was investigated for the macauba biochar obtained at $350{ }^{\circ} \mathrm{C}(\mathrm{BC} 350)$ in order to optimize the adsorption conditions for the removal of U (VI) from aqueous solutions. The selection of the optimal parameters is part of the preliminary studies which allow to maximize the BC's performance, being very important, not only for the application itself, but for the realization of further experiments and characterizations.

\section{MATERIALS AND METHODS}

\subsection{Materials}

The macaúba coconut endocarp was supplied by Soleá (João Pinheiro, MG, Brazil). After skin and pulp removal from the coconut, the chestnut, constituted by the endocarp and almond, was broken using a jaw crusher, allowing the separation of the endocarp.

A standard solution of $1000 \mathrm{mg} \mathrm{L}^{-1}$ of uranium was prepared by dissolution of a $\mathrm{U}_{3} \mathrm{O}_{8}$ certified reference material (CRM 129-A, natural ${ }^{238} \mathrm{U}$ ) supplied by New Brunswick Laboratory (New Brunswick, NJ, USA). This solution was used to prepare diluted solutions used for adsorption and calibration experiments. All solutions were prepared using ultrapure water (18.2 $\mathrm{M} \Omega \mathrm{cm}$ resistivity) and Merck's analytical grade nitric acid, $\mathrm{HNO}_{3} 65 \%$ (Darmstadt, Germany).

\subsection{Sample preparation}


After sampling for removal of dirt and unbroken coconuts, the endocarp were shredded in a cutting mill passing over a $3 / 8 \mathrm{Mesh}$ screen and subsequently oven-dried at $100{ }^{\circ} \mathrm{C}$ for 3 hours.

\subsection{Biochar production}

Pyrolysis of the endocarp was conducted using a Thermo Fisher (Asheville, NC, USA), Lindberg Blue M, horizontal tubular steel reactor heated by an electric furnace at the Laboratory of Recycling, Waste Treatment and Extraction (Polytechnic School, University of Sao Paulo) under inert argon atmosphere. Six different temperatures were independently adjusted and ranged from $250^{\circ} \mathrm{C}$ to $750^{\circ} \mathrm{C}$. The carbonized samples were identified as "BCT", in which "T" corresponds to the HTT; for instance: $\mathrm{BC} 250$ when the HTT is $250^{\circ} \mathrm{C}$. The dried endocarp was subjected to six different HTTs, as shown in Table 1.

For each HTT, approximately $30 \mathrm{~g}$ of endocarp was processed applying an argon (Ar) gas flow of $40 \mathrm{~mL} \mathrm{~min}^{-1}$. The sample was kept at each HTT for $1 \mathrm{~h}$ (residence time). By the end of the process, the furnace was switched off and the reactor was allowed to cool.

Table 1: Pyrolysis heating steps at a heating rate of $5{ }^{\circ} \mathrm{C} \min ^{-1}$.

\begin{tabular}{ccccccc}
\hline Steps & $\mathbf{2 5 0}^{\circ} \mathbf{C}$ & $\mathbf{3 5 0}^{\circ} \mathbf{C}$ & $\mathbf{4 5 0}^{\circ} \mathbf{C}$ & $\mathbf{5 5 0}^{\circ} \mathbf{C}$ & $\mathbf{6 5 0}^{\circ} \mathbf{C}$ & $\mathbf{7 5 0}^{\circ} \mathbf{C}$ \\
\hline $\mathbf{1}$ & 50 min & & & & & \\
$\mathbf{2}$ & & 70 min & & & & \\
$\mathbf{3}$ & & & $90 \mathrm{~min}$ & & & \\
$\mathbf{4}$ & & & $1 \mathrm{~h} 50$ & & \\
$\mathbf{5}$ & & & & $2 \mathrm{~h} 10$ & \\
$\mathbf{6}$ & & & & & $2 \mathrm{~h} 30$ \\
\hline
\end{tabular}

The argon flow proceeded during the cooling process in order to purge the reactor of any remaining pyrolysis gases and to prevent any oxygen exposure of the biochar while still above ignition temperature. 
After that, the alumina crucible containing the biochar was removed from the furnace and allowed to cool at room temperature in a desiccator. Finally, the biochar was ground in a cutting mill passing over a 120 Mesh screen and stored in hermetic polypropylene bottles.

\subsection{Sorption experiments}

Equilibrium adsorption experiments were conducted in triplicates using batch technique and the experiments were performed in a rotary shaker using $100 \mathrm{~mL}$ glass beakers, $120 \mathrm{rpm}$ stirring rate at room temperature $\left(25^{\circ} \mathrm{C}\right)$ during 24 hours contact time, to ensure the attainment of the system's equilibrium. The adsorbent was separated by filtration using a SCP Science (Baie-D'Urfé, QC, Canada) 0.45 micron Teflon membrane filter (DigiFILTER).

The U(VI) concentration in the reminiscent filtrate solution was subjected to a determination by inductively coupled plasma optical emission spectrometry using a Spectro ARCOS ICP OES (Kleve, NRW, Germany). The adsorption of U(VI) was evaluated as a function of $\mathrm{pH}$, adsorbent dose, initial concentration and contact time. The initial $\mathrm{pH}$ was adjusted using $0.1 \mathrm{~mol} \mathrm{~L}^{-1} \mathrm{HNO}_{3}$ and $0.1 \mathrm{~mol} \mathrm{~L}^{-1} \mathrm{NaOH}$ solutions.

The adsorption capacity, $\mathrm{qt}\left(\mathrm{mg} \mathrm{g}^{-1}\right)$, of the adsorbent was calculated using the Eq. (1):

$$
q_{t}=\frac{\left(C_{0}-C_{t}\right) \times V}{M}
$$

where $\mathrm{q}_{\mathrm{t}}$ is the adsorbed amount of adsorbate per gram of adsorbent at any time $\mathrm{t}, \mathrm{C}_{0}$ and $\mathrm{C}_{\mathrm{t}}$ the concentrations of the adsorbate in the initial solution and at any time $\mathrm{t}$, respectively $\left(\mathrm{mg} \mathrm{L}^{-1}\right) ; \mathrm{V}$ the volume of the adsorbate solution added (L) and $\mathrm{M}$ the amount of the adsorbent used ( $\mathrm{g}$ ). The extraction efficiency, $\mathrm{R}(\%)$, was determined through the following equation:

$$
R(\%)=\left(\frac{C_{o}-C_{t}}{C_{o}}\right) \times 100
$$


where $\mathrm{R}$ is the efficiency of extraction or percentage removal, $\mathrm{C}_{0}\left(\mathrm{mg} \mathrm{L}^{-1}\right)$ is the initial concentration of each adsorbate and $\mathrm{C}_{\mathrm{t}}\left(\mathrm{mg} \mathrm{L}^{-1}\right)$ represents the concentration of the adsorbate at time $\mathrm{t}$.

\section{RESULTS AND DISCUSSION}

\subsection{Effect of pH}

The $\mathrm{pH}$ of the aqueous solution affects the surface charge of the adsorbents as well as the degree of ionization and speciation of the solute. The $\mathrm{pH}$ values were evaluated in a range between 2.0 and 7.0, while the other parameters (adsorbent dosage of $10 \mathrm{~g} \mathrm{~L}^{-1}$ and $\mathrm{U}$ initial concentration of $5 \mathrm{mg} \mathrm{L}^{-}$ $\left.{ }^{1}\right)$ were held constant.

BC350 was selected for the preliminary experiments based on a previous study [26], in which the gravimetric yield factor was used to identify the temperature at which to obtain a biochar with the maximum fixed carbon content and gravimetric yield. In this case, the gravimetric yield obtained for BC350 was of $46.09 \%$ and the fixed carbon content was of $60.22 \%$, rendering a gravimetric yield factor of $0.28 \%$, which, by comparison, qualified $350{ }^{\circ} \mathrm{C}$ as the operational HTT.

The influence of $\mathrm{pH}$ on the removal of U(VI) ions onto macauba biochar is presented in Figure 2.

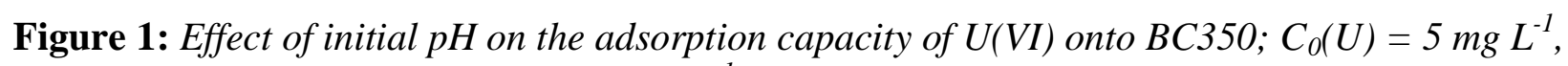
adsorbent dosage $=10 \mathrm{mg} \mathrm{L}^{-1}$, contact time $=24 \mathrm{~h} ; \mathrm{T}=25 \pm 2{ }^{\circ} \mathrm{C}$. 


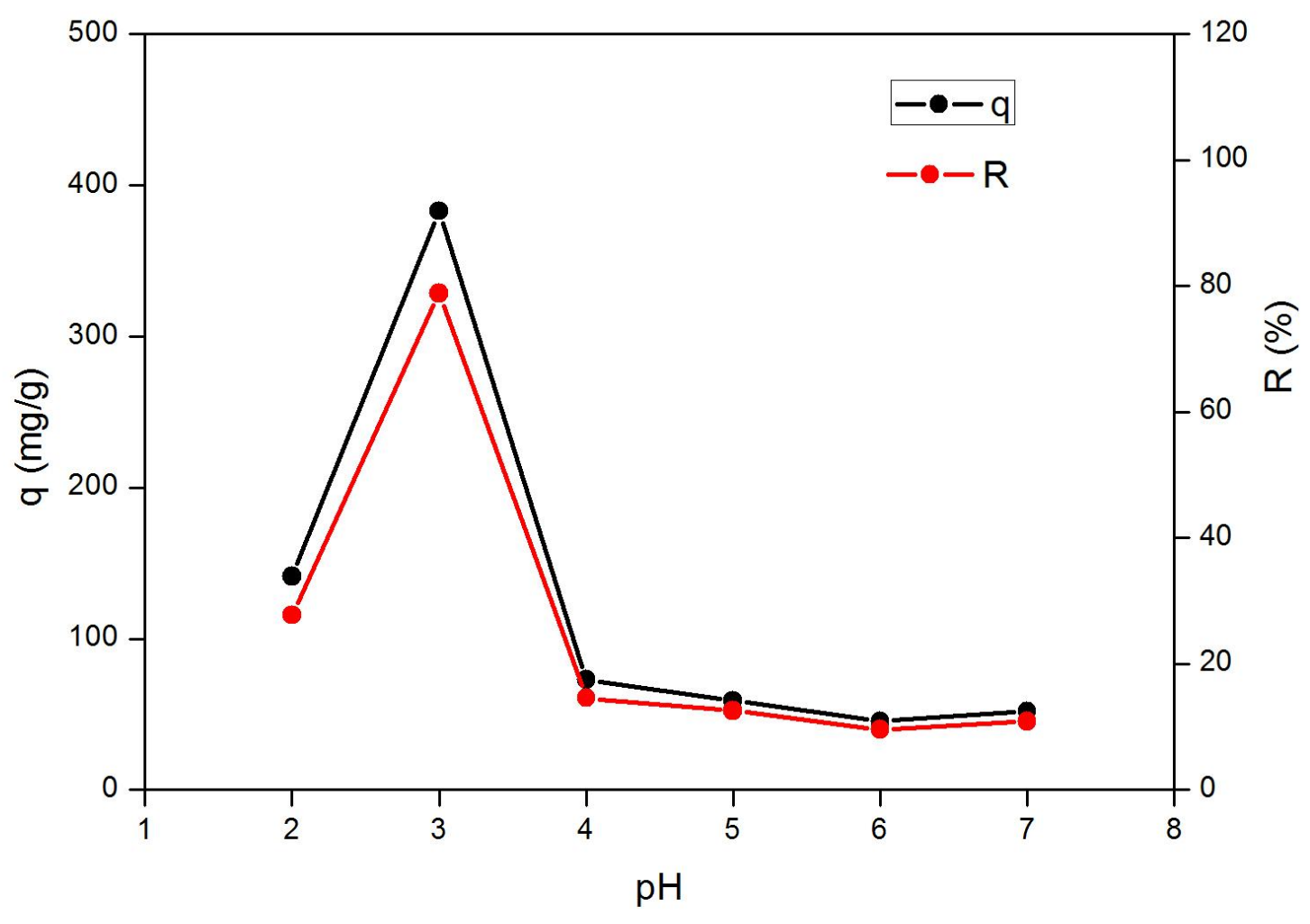

As can be seen in Figure 2, the adsorption ability for uranium onto BC350 strongly depends of the $\mathrm{pH}$ value. The uptake amount of $\mathrm{U}(\mathrm{VI})$ reached the maximum adsorption capacity at $\mathrm{pH}$ 3.0. At lower $\mathrm{pH}$ values $(\mathrm{pH}<3.5)$, over $95 \%$ of the uranium is present as free uranyl ions $\left(\mathrm{UO}_{2}{ }^{2+}\right)$. However, when the solution $\mathrm{pH}$ is too low, the amount of protons $\left(\mathrm{H}^{+}\right)$can compete with the uranyl cations for adsorption sites in the biochar. Thus, the adsorption decreases when $\mathrm{pH}<3$. However, as the solution $\mathrm{pH}$ is gradually increased, the presence of different mononuclear and polynuclear uranium (VI) hydrolysis products in the form of $\left[\left(\mathrm{UO}_{2}\right) \mathrm{p}(\mathrm{OH}) \mathrm{q}\right]^{(2 \mathrm{p}-\mathrm{q})+}$ responds for the decrease of the adsorption, since these species have lower affinity with the adsorbent [7].

\subsection{Effect of adsorbent dosage}


The adsorbent dosage is an important parameter because it is associated to the determination of the adsorption capacity of an adsorbent for a given concentration of adsorbate. The adsorption studies of U(VI) onto biochar materials were conducted by varying the adsorbent dosage from 1 to $20 \mathrm{~g} \mathrm{~L}^{-1}$. The influence of adsorbent dosage on adsorption of U(VI) ion is shown in Fig. 3.

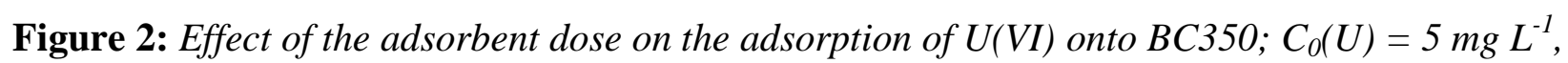
$p H=3$, contact time $=24 \mathrm{~h} ; \mathrm{T}=25 \pm 2{ }^{\circ} \mathrm{C}$.

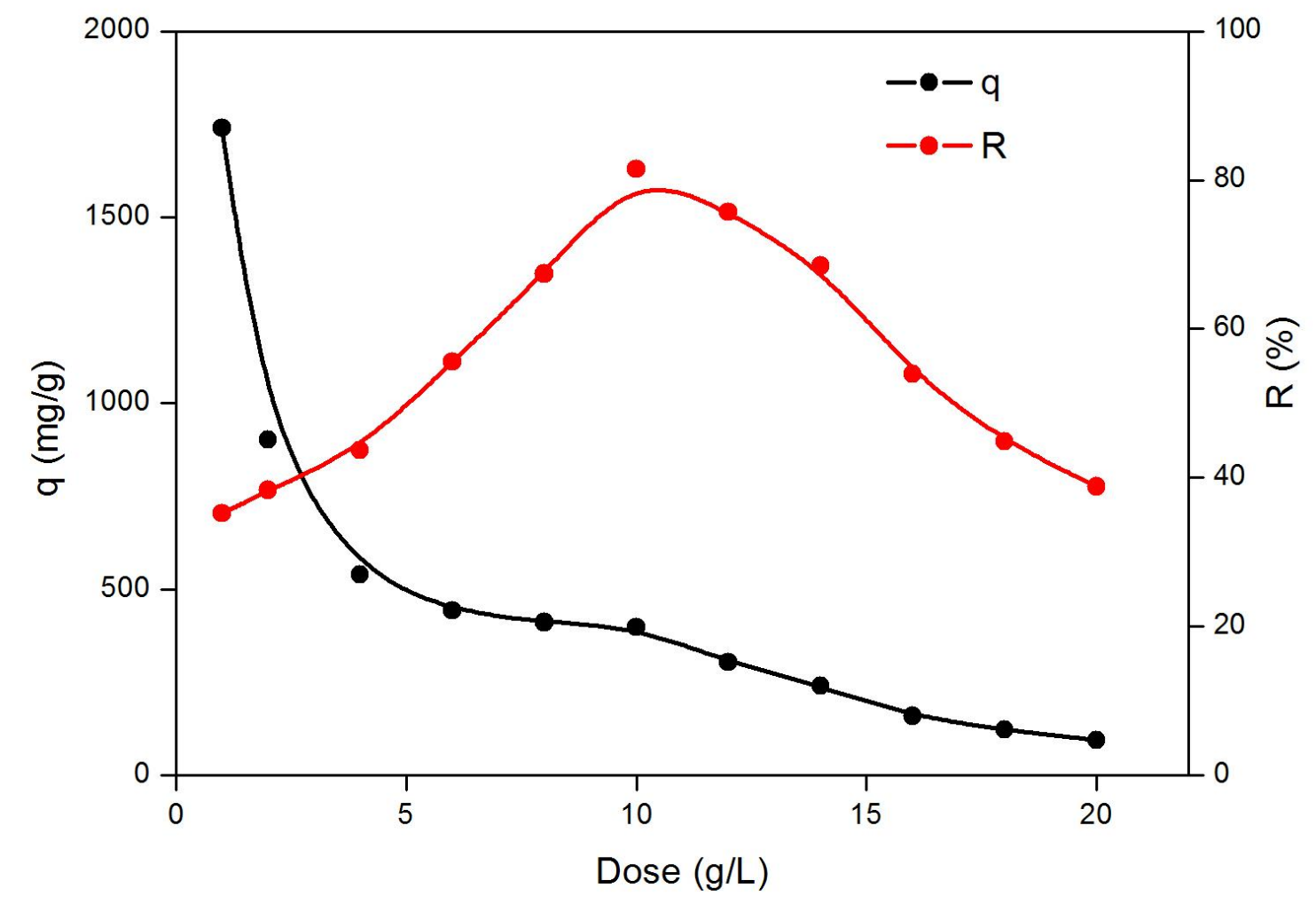

As seen in Figure 3, increasing the adsorbent dose up to $20 \mathrm{~g} \mathrm{~L}^{-1}$ substantially decreases the adsorption capacity (the amount adsorbed per unit mass of adsorbent) for U(VI), which is mainly due to the sites remaining unsaturated during the adsorption process and can be mathematically explained [27]. Another reason may be attributed to the particle interactions, such as aggregation, caused by high adsorbent concentration [28]. Such aggregation would lead to a decrease in the total surface 
area of the adsorbent [29]. Thus, further increase of adsorbent dosage does not afford exhaustive adsorption of U(VI). However, in terms of removal, the maximum effect is observed when a dose of $10 \mathrm{~g} \mathrm{~L}^{-1}$ is used. Therefore, this dose was adopted for adsorption experiments.

\subsection{Effect of initial concentration}

The initial concentration $\left(\mathrm{C}_{0}\right)$ of the $\mathrm{U}(\mathrm{VI})$ aqueous solution was evaluated for a range of concentrations from 1 to $50 \mathrm{mg} \mathrm{L}^{-1}$. The experiments were performed using a dose of sorbent of $10 \mathrm{~g} \mathrm{~L}^{-1}$ and adjusting the solutions to $\mathrm{pH} 3$.

The influence of initial concentration $\left(\mathrm{C}_{0}\right)$ on adsorption of U(VI) ion is shown in Figure 4. An increase of the adsorption capacity (qt) is observed when $\mathrm{C}_{0}$ was increased from 1 to $5 \mathrm{mg} \mathrm{L}^{-1}$, reaching a qt maximum at $5 \mathrm{mg} \mathrm{L}^{-1}$. As the concentration was increased to higher concentrations, a steady decrease of qt was observed until $25 \mathrm{mg} \mathrm{L}^{-1}$ after which it appears to assume a constant behavior.

Figure 3: Effect of the initial concentration on the adsorption of $U(V I)$ onto $B C 350 ; p H=3$; adsorbent dose $=10 \mathrm{~g} \mathrm{~L}^{-1}$; contact time $=24 \mathrm{~h} ; \mathrm{T}=25 \pm 2{ }^{\circ} \mathrm{C}$. 


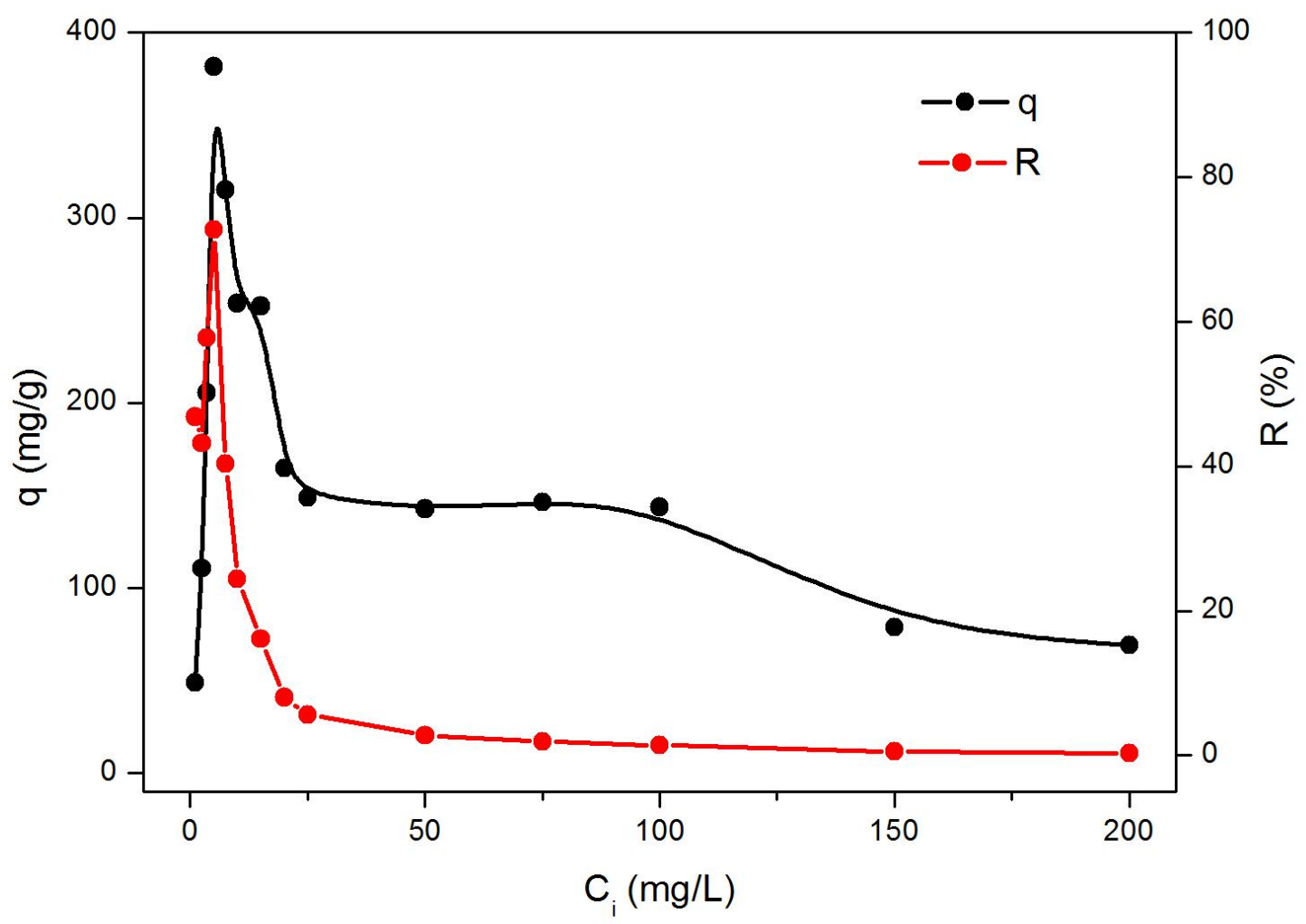

This is in accordance to the selected dose, which was optimized for the given initial concentration $\left(\mathrm{C}_{0}=5 \mathrm{mg} \mathrm{L}^{-1}\right)$. In the event of working with more concentrated solutions, new correlations to other doses should be evaluated.

\subsection{Adsorption on BC350}

The adsorption of $\mathrm{U}$ (VI) onto BC350 was investigated using an initial $\mathrm{U}$ concentration of $5 \mathrm{mg} \mathrm{L}^{-1}$, pH 3 and $10 \mathrm{~g} \mathrm{~L}^{-1}$ biochar dose. The adsorption capacity obtained for BC350 was of $408 \mathrm{mg} \mathrm{g}^{-1}$ and the removal efficiency was of $80.1 \%$. These results point to the promising potential of the macauba biochar as an adsorbent for the treatment of uranium containing aqueous solutions and were enabled through the optimization of the adsorption conditions, at which the BC350 can be applied to its 
maximum efficiency. Additionally, it must be emphasized that the obtained biochar didn't undergo activation steps.

\section{CONCLUSION}

Batch experiments were employed to evaluate the adsorption capacity of the biochar derived from macauba coconut residue for removing uranium ions from aqueous solutions aiming its application for the treatment of liquid wastes and contaminated wastewaters. The biochar was obtained using slow pyrolysis under inert argon atmosphere. The results revealed that the optimal conditions were achieved at $\mathrm{pH} 3$, adsorbent amount of $10 \mathrm{~g} \mathrm{~L}^{-1}$ and $\mathrm{U}(\mathrm{VI})$ initial concentration of $5 \mathrm{mg} \mathrm{L}^{-1}$. A removal efficiency of $80 \%$ was achieved for BC350 using a heating rate of $5{ }^{\circ} \mathrm{C} \mathrm{min}{ }^{-1}$ and a residence time of $1 \mathrm{~h}$. The results demonstrated the potential of the macauba biochar as a value-added material for uranium removal from aqueous radioactive wastes.

\section{ACKNOWLEDGMENT}

Special thanks to Soleá (João Pinheiro, MG, Brazil) for supplying the macauba endocarp.

\section{REFERENCES}

1. NEA/OECD - Nuclear Energy Agency Organization for Economic Co-Operation and Development, Environmental Activities in Uranium Mining and Milling, Paris: OECD, 1999, 177p.

2. SAKR, K.; SAYED, M.S; HAFEZ, M. B. Immobilization of radioactive waste in mixture of cement, clay and polymer. Journal of Radioanalytical Nuclear Chemistry, v. 256, n. 2, p. 179-184, 2003. 
3. OZDEMIR, T.; USANMAZ, A. Use of poly(methyl methacrylate) in radioactive waste management: I, radiation stability and degradation. Progress in Nuclear Energy, v. 51, n. 2, p. 240-245, 2009.

4. IAEA - International Atomic Energy Agency, Combined methods for liquid radioactive waste treatment, IAEA-TECDOC-1336, Vienna: IAEA, 2003, 250p.

5. TSURUTA, T. Removal and recovery of uranyl ion using various microorganisms. Journal of Bioscience and Bioengineering, v. 94, p. 23-28, 2002.

6. ZHANG, X. Z.; LUO, S. G.; YANG, Q.; ZHANG, H. L.; LI, J. Y. Accumulation of uranium at low concentration by green alga Scnenedesmus obliquus. Journal of Applied Phycology, v. 9, p. 64-71, 1997.

7. YI, Z.; YAO, J. ZHU, M.; CHEN, H.; WANG, F.; YUAN, Z.; LIU, X. Batch study of uranium biosorption by Elodea Canadensis biomass. Journal of Radioanalytical Nuclear Chemistry, v. 310, p. 505-513, 2016.

8. WANG, S.; PENG, Y. Natural zeolites as effective adsorbents in water and wastewater treatment. Chemical Engineering Journal, v. 156, p. 11-24, 2010.

9. ZAREH, M. M.; ALDAHER, A.; HUSSEIN, A. E. M.; MAHFOUZ, M. G.; SOLIMAN, M. Uranium adsorption from a liquid waste using thermally and chemically modified bentonite. Journal of Radioanalytical Nuclear Chemistry, v. 295, p. 1153-1159, 2013.

10. ZHANG, X. F.; WANG, J.; LI, R. M.; LIU, Q.; LI, L.; YU, J.; ZHANG, M. L.; LIU, L. H. Efficient removal of uranium (VI) from aqueous systems by heat-treated carbon microspheres. Envionmnetal Science Pollution Research, v. 20, p. 8202-8209, 2013e.

11. AYCIK, G. A.; GURELLIER, R. Comparative studies for the determinations of uranyl ion adsorption onto interpenetrating polymer networks (IPNs). Journal of Radioanalytical Nuclear Chemistry, v. 273, n. 3, p. 713-718, 2007.

12. DE GISI, S.; LOFRANO, G.; GRASSI, M.; NOTARNICOLA, M. Characteristics and adsorption capacities of low-cost sorbents for wastewater treatment: A review. Sustainable Materials and Technologies, v. 9, p. 10-40, 2016.

13. INYANG; M. I.; GAO, B; YAO, Y.; XUE, Y; ZIMMERMAN, A.; MOSA, A; PULLAMMANAPPALLIL, P.; OK, Y. S.; CAO, X.A review of biochar as a low-cost adsorbent for aqueous heavy metal removal. Critical Reviews in Environmental Science and Technology, v. 46, n. 4, 2016.

14. PATRA, J. M.; PANDA, S. S.; DHAL, N. K. Biochar as a low-cost adsorbent for heavy metal removal: A review. Internat $\mathbf{J}$ of Res in Biosci, v. 6, n. 1, p. 1-7, 2017.

15. ZHANG, Z. B.; CAO, X. H.; LIANG, P.; LIU, Y. H. Adsorption of uranium from aqueous solution using biochar produced by hydrothermal carbonization. Journal of Radioanalytical Nuclear Chemistry, v. 295, p. 1201-1208, 2013d. 
16. KUMAR, S.; LOGANATHAN, V. A.; GUPTA, R. B.; BARNETT, M. O. An assessment of U (VI) removal from groundwater using biochar produced from hydrothermal carbonization. Journal of Environmental Management, v. 92, p. 2504-2512, 2011.

17. WANG, S.; GUO, W.; GAO, F.; WANG, Y.; GAO, Y. Lead and uranium sorptive removal from aqueous solution using magnetic and nonmagnetic fast pyrolysis rice husk biochars. RSC Advances, v. 24, 2018.

18. MISHRA, V.; SURESHKUMAR, M. K.; GUPTA, N.; KAUSHK, C. P. Study on sorption characteristics of uranium onto biochar derived from eucalyptus wood. Water, Air, \& Soil Pollution, v. 228, n. 8, 2017.

19. LEHMANN, S. J. Biochar for Environmental Management, $1^{\text {st }}$ ed. Oxford: Earthscan, 2009.

20. BRIDGWATER, A. V.; PEACOCKE, G. V. C. Fast pyrolysis processes for biomass. Renewable Sustainable Energy Reviews, v. 4, p. 1-73, 2000.

21. LU, Q.; LI, W-Z;; ZHU, X-F. Overview of fuel properties of biomass fast pyrolysis oils. Energy Conversion and Management, v. 50, p. 1376-1383, 2009.

22. ANTAL, M. J. J.; GRONLI, M. The art, science, and technology of charcoal production. Industrial and Engineering Chemistry Research, v. 42, p. 1619-1640, 2003.

23. LUA, A. C.; YANG, T.; GUO, J. Effects of pyrolysis conditions on the properties of activated carbons prepared from pistachio-nut shells. Journal of Analytical and Applied Pyrolysis, v. 72, p. 279-287, 2004.

24. ÖZÇIMEN, D.; ERSOY-MERIÇBOYU, A. A study on the carbonisation of grapeseed and chestnut shell. Fuel Processing Technology, v. 89, p. 1041-1046, 2008.

25. RIOS, R. D. F.; FONSECA, R. M.; CREN, E. C.; ANDRADE, M. H. C. Adsorção de fenol no carvão ativado produzido a partir do endocarpo do fruto da macaúba. In: XX Congresso Brasileiro de Engenharia Química, 2014, Florianópolis. Annals... Florianópolis: COBEQ 2014.

26. GUILHEN, S. N.; MASEK, O.; ORTIZ, N.; FUNGARO, D. A. Pyrolytic temperature evaluation of macauba biochar for uranium adsorption from aqueous solutions. In: Biochar: Production, Characterization and Applications Conference, 2017, Alba, Annals... Alba: ECI Conference, 2017.

27. ROYER, B.; CARDOSO, N. F.; LIMA, E. C.; RUIZ, V. S. O.; MACEDO, T. R.; AIROLDI, C. Organofunctionalized kenyaite for dye removal from aqueous solution. Journal of Colloid and Interface Science, v. 336, p. 398-405, 2009.

28. ÖZACAR, M.; SENGIL, I. A.Adsorption of metal complex dyes from aqueous solutions by pine sawdust. Bioresource Technology, v. 96, p. 791-795, 2005.

29. SHUKLA, A.; ZHANG, Y. H.; DUBEY, P.; MARGRAVE, J. L.; SHUKLA, S. S. The role of sawdust in the removal of unwanted materials from water. J Hazard Mat, v. 95, p. 137-152, 2002. 
